\title{
THE SAFETY PROFILE OF THE ANESTHETIC EFFECT OF ALFAXALONE AND ITS INTERACTION WITH XYLAZINE AND KETAMINE IN CHICK'S MODEL (GALLUS GALLUS DOMESTICUS)
}

\author{
Amjed Najem Alatrushi, Ahmed Salah Naser \\ Department of Physiology, Biochemistry and Pharmacology, \\ College of Veterinary Medicine, University of Mosul, Mosul, Iraq
}

Received 18 February 2021; Received in revised form 7 August 2021; Accepted 12 August 2021

\begin{abstract}
The objective of our research was to estimate the therapeutic index and assess the interaction of alfaxalone (IP) with ketamine or xylazine (IM) in chicks by using isobolographic analysis. The up-and-down technique was involved to calculate the median effective anesthetic dosages $\left(\mathrm{ED}_{50}\right)$ of alfaxalone, xylazine, and ketamine given separately or at the same time in young chicks. Then the up-and-down technique was involved to estimate the median lethal dosage $\left(\mathrm{LD}_{50}\right)$ of alfaxalone (IP) to determine the safety profile. The $\mathrm{ED}_{50}$ of all anesthetics was evaluated isobolographically to assess the type of interaction between alfaxalone and xylazine or alfaxalone and ketamine. The alfaxalone $\mathrm{ED}_{50}$ was $32.88 \mathrm{mg} / \mathrm{kg}(\mathrm{IP})$, whereas the $\mathrm{LD}_{50}$ was $102.40 \mathrm{mg} / \mathrm{kg}$ (IP). The $\mathrm{ED}_{50}$ values for alfaxalone, ketamine, and xylazine were $32.88,12.24$, and $2.45 \mathrm{mg} / \mathrm{kg}$, respectively. The $\mathrm{ED}_{50}$ values of alfaxalone with ketamine or xylazine $\left(25: 25 \mathrm{ED}_{50}\right.$ values $)$ were: $7.39+2.35$, and $8.61+0.63 \mathrm{mg} / \mathrm{kg}$, respectively. $\mathrm{ED}_{50}$ values were decreased when the combinations of alfaxalone/ketamine or alfaxalone/xylazine were administered by $22-21 \%$ and $26-25 \%$, respectively. The anesthesia of chicks with alfaxalone is safe, produces a surgical stage of anesthesia, and can be used for minor surgical procedures. The use of alfaxalone with ketamine or xylazine has been shown to have a synergistic effect and these findings may be of clinical relevance in poultry or may be extended to mammals following further clinical trials.
\end{abstract}

Key words: alfaxalone, isobolographic analysis, therapeutic index, chicks, anesthesia

\section{INTRODUCTION}

Surgery and painful complications like fractures, trauma, superficial corneal ulcer, and cloacal prolapse are frequently related to avian patients in veterinary hospitals. Anesthesia, therefore, plays an important role in the routine avian veterinary medicine practice. These procedures are distinct from mammalian medicine mainly because of the physiological and anatomical differences (1). The basic cardiovascular and respiratory system anatomy and physiology are very distinct from

Corresponding author: Ahmed Salah Naser, $\mathrm{PhD}$

E-mail address: ahmadphd0@gmail.com

Present address: Department of Physiology, Biochemistry and

Pharmacology, College of Veterinary Medicine,

University of Mosul, Mosul, Iraq

Phone: +9647702012166

Copyright: (C) 2021 Alatrushi A.N. This is an open-access article published under the terms of the Creative Commons Attribution License which permits unrestricted use, distribution, and reproduction in any medium, provided the original author and source are credited.

Competing Interests: The authors have declared that no competing interests exist.

Available Online First: 6 September 2021

Published on: 15 October 2021

https://doi.org/10.2478/macvetrev-2021-0025 mammals rendering chicks to be more vulnerable to anesthetics (2). In contrast to other vertebrates, the poultry respiratory system has different ventilating mechanisms and exchange partitions (3).

Alfaxalone is a neuroactive steroidal anesthetic with a moderately acceptable safety margin and low cardiovascular or respiratory complications (4). It has a mechanism of action resembling propofol and barbiturates, by achieving agonist activity on gamma-aminobutyric acid (GABA) receptors, subtype-A in the central nervous system (CNS). GABA is an essential part of the CNS neurotransmitter. Alfaxalone increases GABA's effects on its receptors by triggering ion channel opening and chloride ion inflow in the cell. This contributes to cell hyperpolarization and neuronal impulse transmission suppression. This effect is not cumulative and can be maintained by continuous rate infusion (5). In the last years, a combination of $9 \mathrm{mg} / \mathrm{ml}$ alfaxalone and $3 \mathrm{mg} / \mathrm{ml}$ alphadalone acetate was commercially available as a neurosteroid medication (Saffan, Schering- 
Plough Animal Health, UK). This formulation was associated with severe adverse reactions in dogs related to histamine release and anaphylaxis. The solubilizing agent cremophor, a derivative of castor oil, was reported to be responsible for this adverse effect (6). In an effort to eradicate the side effects detected with drug carriers as Cremophor EL, Brewster et al suggested that alfaxalone and other drugs could be solubilized in safe carriers as hydroxypropyl-beta-cyclodextrin (HP- $\beta-\mathrm{CD})(7)$.

Ketamine is a dissociative anesthetic agent inducing dose-dependent unconsciousness and analgesia without muscle relaxation. Xylazine is an $\alpha 2$-agonist that has sedative, antinociceptive, and muscle relaxant effects. Both drugs have been reported to be used in single doses in avian species (8). Their combined use for intravenous injection was reported to achieve "balanced anesthesia" compared to the separate use in single doses $(9,10)$. This mixture offers quicker activation and safer recovery unlike ketamine alone $(8,11)$, whereas the sedative and antinociception effects of xylazine were improved (11).

Isobolographic analysis determines if the biological effects induced by a mixture of medications are higher, equivalent, or smaller than the expected effects of the individual components taking into consideration the dose additivity. Isobolographic analysis which is restricted to binary mixtures offers an unambiguous logical algebraic model for assessing the relationship between ternary and higher-order mixtures (12).

The objective of this research was to investigate the therapeutic safety of alfaxalone and its drug interaction with ketamine or xylazine in chicks (Gallus gallus domesticus).

\section{MATERIAL AND METHODS}

Chicks of both sexes ( $\mathrm{N}=28)$, age between 7 and 12 days, and body weight ranging from 70 to $110 \mathrm{~g}$ were used for the experiment. They were kept in 2 cages $(75 \times 100 \times 50 \mathrm{~cm}, 25$ chicks per cage $)$ with wood shavings litter and were under constant light regime at $30-33{ }^{\circ} \mathrm{C}$ (the ideal temperature at this age of chicks). Food and water were available ad libitum. Alfaxalone (10 mg/ml, ALFAXAN®Multidose, Jurox Pty. Ltd., Rutherford, NSW, Australia) was diluted in a $5 \mathrm{ml}$ volume of distilled water and was injected intraperitoneally (IP) in a dose of $5 \mathrm{ml} / \mathrm{kg}$. Xylazine hydrochloride (2\%, Xylo, Holland) and Ketamine hydrochloride (10\% injectable solution, DOPHARMA Netherland) were diluted in a $5 \mathrm{ml}$ volume of distilled water and were injected intramuscularly (IM) in a dose of $5 \mathrm{ml} / \mathrm{kg}$. This study was approved by the Specialist Science Committee of the University of Mosul, College of Veterinary Medicine (approval number UM.VET.2021.1).

\section{Experiments}

Estimation of the anesthetic $E D_{50}$ of alfaxalone in chicks

The alfaxalone $\mathrm{ED}_{50}$ was estimated with the up-and-down method (13). The chicks were monitored for anesthesia onset (losing the righting reflex and unconsciousness) within two hours. The doses of alfaxalone were decreased or increased by $10 \mathrm{mg}$ depending on the anesthetic effect $(14,15)$. The $\mathrm{ED}_{50}$ value was calculated as follows:

$\mathrm{ED}_{50}$ value $=\mathrm{xf}+\mathrm{K} \mathrm{d}$

Where: $\mathrm{xf}=$ the last dose injected

$\mathrm{K}=$ Table's value from Dixon, 1980 (depend on $\mathrm{X}$ and $\mathrm{O}$ symbols obtained)

$\mathrm{d}=$ increase or decrease in the dosage

Ataxia, relaxation, closed eyelids, loss of righting reflex, and sleep within 1-2 minutes were considered as positive signs of anesthesia induced by alfaxalone (16).

\section{Estimation of $L D_{50}$ of alfaxalone in chicks}

The up-and-down method was used for the estimation of alfaxalone $\mathrm{LD}_{50}$ (13). The chicks were monitored for 24 hours for the onset of toxic effects with an initial dose of $80 \mathrm{mg} / \mathrm{kg}$ alfaxalone. The dose was lowered or increased by $20 \mathrm{mg}$ until the onset of death. The same method of estimation was used for $\mathrm{ED}_{50}$. The signs of toxicity were recumbency, tachycardia, and tachypnea, followed by apnea and death within 20-30 minutes.

\section{Drug safety of alfaxalone estimated by safety indices}

The estimated $\mathrm{ED}_{50}$ and $\mathrm{LD}_{50}$ values of alfaxalone were used for the interpretation and extrapolation of the drug safety of alfaxalone by using the following equations: $\mathrm{TI}=\mathrm{LD}_{50} \backslash \mathrm{ED}_{50}$ (higher TI values are correlated with higher drug safety); $\mathrm{SSM}=\left(\mathrm{LD}_{1} \backslash \mathrm{ED}_{99}-1\right) \times 100\left(\mathrm{LD}_{1}\right.$ is lowest lethal dose in $1 \%$ of the experimental sample and $\mathrm{ED}_{99}$ is the minimum dose wanted to create the therapeutic effect in $99 \%$ of the experimental sample; higher SSM values are correlated with higher drug safety); The therapeutic ratio (TR) is the ratio of the lethal dose-25 $\left(\mathrm{LD}_{25}\right)$ and the effective dose-75 $\left(\mathrm{ED}_{75}\right)$; $\mathrm{TR}=\mathrm{LD}_{25} / \mathrm{ED}_{75}$ where $\mathrm{LD}_{25}$ is the dose that is lethal for $25 \%$ of the animals and $\mathrm{ED}_{75}$ is the dose that 
is effective for $75 \%$ of the animals (17). TR was used as a superior index of drug safety because it includes the curve sharpness.

\section{Isobolographic analysis}

The estimated $\mathrm{ED}_{50}$ of alfaxalone, ketamine, and xylazine, as well as the $\mathrm{ED}_{50}$ of alfaxalone/ketamine and alfaxalone/xylazine (25:25 of their individual anesthetic $\mathrm{ED}_{50}$ values), were used for the isobolographic analysis which determined the level of drug interaction. The induction of anesthesia was confirmed by loss of righting reflex and consciousness within 30 minutes $(15,18)$. The $\mathrm{ED}_{50}$ value of alfaxalone was marked on the $\mathrm{x}$-axis and those of ketamine and xylazine on the $y$-axis, connected by a straight diagonal line. The $\mathrm{ED}_{50}$ values of the combined treatments on, above, or beneath the diagonal line were considered as an additive, antagonistic, or synergistic effect, respectively $(12,19,20,21)$. The interaction index (Y) was estimated with the following equation $\mathrm{da} / \mathrm{Da}+\mathrm{db} / \mathrm{Db}$ (20), where ' $\mathrm{Da}$ ' and ' $\mathrm{Db}$ ' represent the anesthetic $\mathrm{ED}_{50}$ of alfaxalone, and ketamine or xylazine respectively, while da and db are the $\mathrm{ED}_{50}$ of alfaxalone/ketamine or alfaxalone/xylazine. The values of the Y-index were interpreted as follows: $\mathrm{Y}=1$ - additive, $\mathrm{Y}<1$ - synergistic, and $\mathrm{Y}>1$ antagonistic effect $(15,19)$.

\section{RESULTS}

Estimation of the anesthetic $E D_{50}$ of alfaxalone in chicks

The $\mathrm{ED}_{50}$ of alfaxalone was $32.88 \mathrm{mg} / \mathrm{kg}$ IP (16).

Estimation of acute $L D_{50}$ of alfaxalone in chicks

The $\mathrm{LD}_{50}$ of alfaxalone was $102.4 \mathrm{mg} / \mathrm{kg}$ IP (Table 1).

Drug safety of alfaxalone estimated by safety indices

According to the $\mathrm{ED}_{50}$ and $\mathrm{LD}_{50}$ values of alfaxalone, the TI was estimated 3.1. The TI number means that the effective dose $\left(\mathrm{ED}_{50}\right)$ used

Table 1. Median lethal dose $\left(\mathrm{LD}_{50}\right)$ of alfaxalone injected intraperitoneally in chicks

\begin{tabular}{ll}
\hline Parameters & Results \\
\hline $\mathbf{L D}_{\mathbf{5 0}}(\mathbf{m g} / \mathbf{k g})$ & 102.4 \\
Dose range (mg/kg) & $120-80=40$ \\
Initial dose (mg/kg) & 80 \\
Final dose (mg/kg) & 120 \\
Dose deviation ( $\mathbf{m g} / \mathbf{k g})$ & 20 \\
Number of chicks $(\mathbf{X}-\mathbf{d e a d} ;$ Alive-O) & $\mathrm{X}=2, \mathrm{O}=3$ \\
Time of death onset (min) & $20-30$
\end{tabular}

$\mathrm{X}$ : death; O: no death

Table 2. Drug safety of alfaxalone as estimated by safety indices in chicks

\begin{tabular}{lc}
\hline Parameters & Results \\
\hline TI & 3.110 \\
SSM (\%) & 3.194 \\
TR (\%) & 1.038 \\
\hline
\end{tabular}

$\mathrm{TI}=\mathrm{LD}_{50} \backslash \mathrm{ED}_{50} ; \mathrm{SSM}=\left(\mathrm{LD}_{1} \backslash \mathrm{ED}_{99}-1\right) \times 100 ; \mathrm{TR}=$ Therapeutic Ratio 
Table 3. Percentages of decline in the anesthetic effect $\left(\mathrm{ED}_{50}\right)$ of alfaxalone/ketamine and alfaxalone/xylazine in chicks and interaction indices $(\mathrm{Y})$

\begin{tabular}{lcc}
\hline Drug's mixtures & The percentage of decline in anesthetic $\mathbf{E D}_{\mathbf{5 0}}$ & $\mathbf{Y}$ \\
\hline Alfaxalone /ketamine & $22+21$ & 0.43 \\
Alfaxalone /xylazine & $26+25$ & 0.52 \\
\hline
\end{tabular}

* $\mathrm{Y}=1$ Additive effect, $<1$ synergistic effect, and $>1$ antagonistic effect

$\mathrm{n}=5-8$ chicks $/$ for each $\mathrm{ED}_{50}$ trial

of alfaxalone should be multiplied 3 times to induce the toxic effect of alfaxalone and kill $50 \%$ of the animals $\left(\mathrm{LD}_{50}\right)$ (Table 2$)$.

In contrast, the SSM value was $3.194 \%$. The SSM calculated $(100 \%)$ means that the effective dose of alfaxalone $\left(\mathrm{ED}_{99}\right)$ that produces $99 \%$ anesthesia in animals should be increased by $100 \%$ (i.e., from 8.514 to $17.028 \mathrm{mg} / \mathrm{kg}$, IM) to kill $1 \%$ of the animals $\left(\mathrm{LD}_{1}\right)$ and produces its toxic and deleterious effects. Thus, the TI and SSM values reflect that alfaxalone possesses a preferable wide margin of safety. Therapeutic Ratio (TR) was 1.038.

\section{Isobolographic analysis}

The anesthetic $\mathrm{ED}_{50}$ values for alfaxalone, ketamine, and xylazine were $32.88,12.24$ and

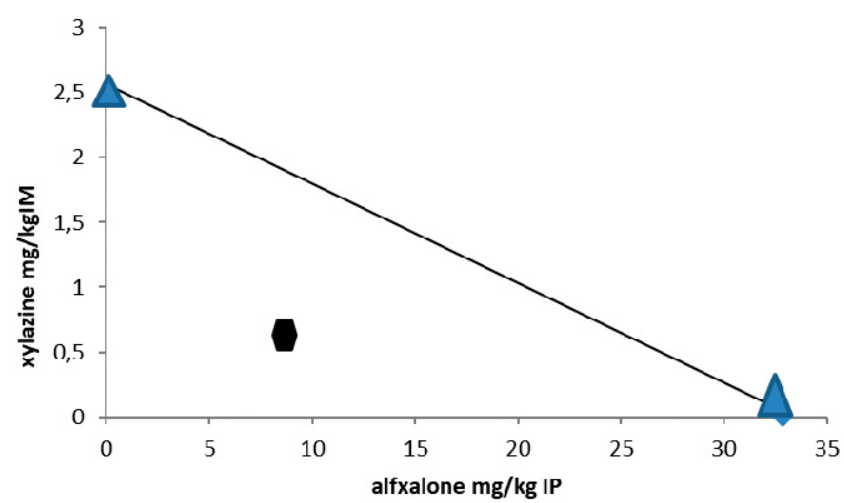

Figure 1. Isobolographic analysis of the anesthetic interaction of alfaxalone and xylazine in the chicks. Points on $\mathrm{x}$ - and y-axes characterize median anesthetic doses $\left(\mathrm{ED}_{50 \mathrm{~s}}, \mathrm{mg} / \mathrm{kg}\right)$ administered separately, while the circular point characterizes 25:25 of $\mathrm{ED}_{50}$ co-administration of both anesthetics. The diagonal line between the individual $\mathrm{ED}_{50 \mathrm{~s}}$ of alfaxalone and xylazine is synergism and the circular below the line refers to synergistic interaction. $\mathrm{n}=5$ chicks/trial

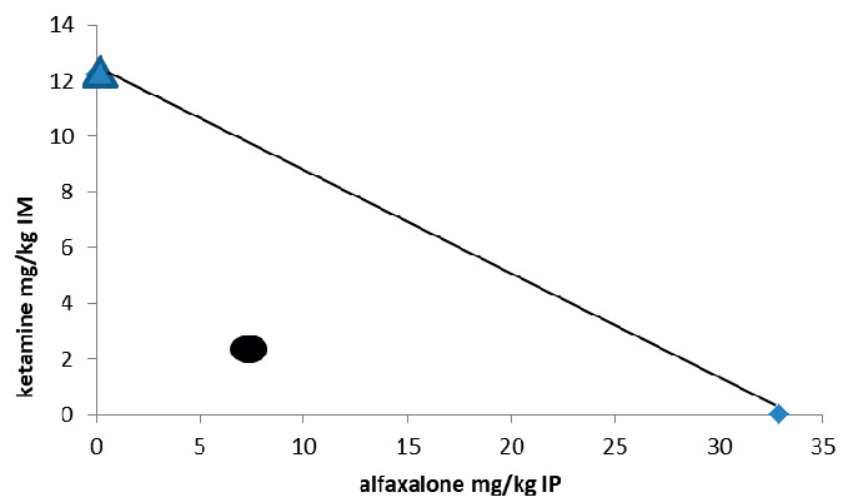

Figure 2. Isobolographic analysis of the anesthetic interaction of alfaxalone and ketamine in the chicks. Points on x- and $\mathrm{y}$-axes characterize median anesthetic doses $\left(\mathrm{ED}_{50 \mathrm{~s}}, \mathrm{mg} / \mathrm{kg}\right)$ of the anesthetics administered separately, while the circular point characterizes 25:25 of $\mathrm{ED}_{50}$ co-administration of both anesthetics. The diagonal line between the individual $\mathrm{ED}_{50 \text { s }}$ of alfaxalone and ketamine is synergism and the circular below the line refers to synergistic interaction. $\mathrm{n}=8 \mathrm{chicks} /$ trial 
$2.45 \mathrm{mg} / \mathrm{kg}$, respectively. Coadministrations of alfaxalone/ketamine or alfaxalone/xylazine had an additive effect on $\mathrm{ED}_{50}$ values $7.39+2.35$ and $8.61+0.63 \mathrm{mg} / \mathrm{kg}$, respectively. The $\mathrm{ED}_{50}$ of alfaxalone/ketamine and alfaxalone/xylazine declined by $22-21 \%$ and $26-25 \%$, respectively (Table 3). Isobolographic analysis of $\mathrm{ED}_{50}$ of the 3 anesthetics (either separately or combined) showed synergistic effects between alfaxalone/ketamine or alfaxalone/xylazine in the chicks (Fig. 1) and (Fig. 2). The synergistic interaction was determined by the location of the $\mathrm{ED}_{50}$ points of alfaxalone/ketamine and alfaxalone/xylazine beneath the diagonal line that joins their individual anesthetic $\mathrm{ED}_{50}$ values (Fig. 1 and Fig. 2).

\section{DISCUSSION}

The purpose of this research was to assess alfaxalone general anesthesia profile in chicks and to evaluate the additive effects of xylazine or ketamine by increasing the anesthetic period and the anesthetic efficacy. The anesthetic efficacy was confirmed by the overall balance of anesthesia characterized by unconsciousness, analgesia, muscle relaxation, and minimal degree of reflexes. Alfaxalone was reported to induce general anesthesia at $10 \mathrm{mg} / \mathrm{kg}$ in several wild reptile species (22). Smith and Rodriguez-Barbon (23) reported a dose of $5-10 \mathrm{mg} / \mathrm{kg}$ IV or IM for waterbirds, but they did not provide the exact safety margin. The use of cyclodextrin with alfaxalone is poorly reported. The combination of alfaxalonealphadalone, previously used with cremophor, was reported in several avian species. A similar finding was expected to be obtained in the current formulation. The alfaxalone/alfadolone dose for budgerigar was reported 16 and $156 \mathrm{mg} / \mathrm{kg}$ IM or IP, respectively (24). Hence, the route of drug administration is a crucial factor for the anesthetic dose. Due to the difficulty of IV administration of alfaxalone in chicks, we found that the anesthesia induction dose is larger than the IV-injected dose. According to the results of TI, SSM, and TR, we found that the alfaxalone is safe and has a good margin of safety. Due to the wide therapeutic index between $\mathrm{ED}_{50}$ and $\mathrm{LD}_{50}$, the alfaxalone dose could be increased threefold before initiating its toxic effects. A flatter curve is representing a higher toxic effect, hence the hyperreactive groups are at a much greater risk than the hyperactive or normal groups. Shallower curves usually have low therapeutic ratios (17). Several studies have investigated the drug interaction between alfaxalone with xylazine (25), ketamine (26) in mice, rats (27), and horses (28).

In the current study, the anesthetic effect of alfaxalone/ketamine or alfaxalone/xylazine combinations was found to be synergetic. The isobolographic analysis showed that the anesthetics should be combined in a 0.25:0.25 ratio in respect of their individual $\mathrm{ED}_{50}$ values. The resulting interaction index was $<1$ ( 0.43 and 0.52 , respectively). The synergistic effect in achieving central depression may be due to the different anesthetic mechanisms.

Synergistic effects between alfaxalone and midazolam have been described in dogs (29) and cats (30). It seems that the addition of ketamine and xylazine resulted in balanced and durable anesthesia for dogs, cats (16), and mice $(25,26)$. The higher anesthetic effect achieved with a low-dose alfaxalone in combination with ketamine or xylazine in chicks compared to mice could be attributed to the physiologic adaptations including a higher metabolic rate in the rodents (31).

\section{CONCLUSION}

The result from this research indicated that the use of alfaxalone was effective and safe anesthetic for short-duration surgical procedures in chicks. Moreover, it was more efficient when combined with ketamine or xylazine by achieving balanced anesthesia. This effect was observed with a lower dose of alfaxalone combined with ketamine or xylazine. These findings may be beneficial in extrapolation of the results to the mammalian species in further research.

\section{CONFLICT OF INTEREST}

The authors declare that they have no potential conflicts of interest.

\section{ACKNOWLEDGMENTS}

The study was supported by the College of Veterinary Medicine, University of Mosul, Iraq.

\section{AUTHORS' CONTRIBUTIONS}

ASN and AA have played a major part in designing, acquiring, analyzing, and interpreting data, performed the statistical analysis, wrote and have critically reviewed 
the article for essential intellectual elements, approved the final version to be issued. They were equally involved in the planning, analysis, evaluation, and writing of the article.

\section{REFERENCES}

1. Lierz, M., Korbel, R. (2012). Anesthesia and analgesia in birds. J Exot Pet Med. 21(1): 44-58. https://doi.org/10.1053/j.jepm.2011.11.008

2. Lichtenberger, M. (2007). Shock and cardiopulmonary-cerebral resuscitation in small mammals and birds. Vet Clin North Am Exot Anim Pract. 10(2): 275-291.

https://doi.org/10.1016/j.cvex.2007.02.001

3. Zehnder, A.M., Hawkins, M.G., Pascoe, P.J. (2014). Avian anatomy and physiology. In: G. West, D. Heard, N. Caulket (Eds.), Zoo animal and wild life immobilisation and anesthesia (pp. 389-398). New York: Wiley-Blackwell https://doi.org/10.1002/9781118792919.ch23

4. Palmer, D. (2019). Veterinary Therapeutics. In: M. Tighe, M. Brown (Eds.), Mosby's comprehensive review for veterinary technicians. Part 3 (p. 419). Amsterdam: Elsevier

5. Duke-Novakovski, T. (2015). Ten intravenous anesthetic induction drugs. Quest Answers Small Anim Anesth. 73. Philadelphia: Elsevier Saunders https://doi.org/10.1002/9781118912997.ch10

6. Child, K.J., Currie, J.P., Davis, B., Dodds, M.G., Pearce, D.R., Twissell, D.J. (1971). The pharmacological properties in animals of CT1341-a new steroid anaesthetic agent. BJA Br J Anaesth. 43(1): 2-13.

https://doi.org/10.1093/bja/43.1.2-a

7. Brewster, M.E., Estes, K.S., Bodor, N. (1990). An intravenous toxicity study of 2-hydroxypropyl$\beta$-cyclodextrin, a useful drug solubilizer, in rats and monkeys. Int J Pharm. 59(3): 231-243. https://doi.org/10.1016/0378-5173(90)90114-J

8. Green, C.J., Knight, J., Precious, S., Simpkin, S. (1981). Ketamine alone and combined with diazepam or xylazine in laboratory animals: a 10 year experience. Lab Anim. 15(2): 163-170. https://doi.org/10.1258/002367781780959107

9. Elowni, E.E., Sanhouri, A.A., Dafalla, R.A., Makky, E.A.M., Aldood, M.E., Yassin, M.A. (2019). Evaluation of ketamine as a general anesthetic for domestic fowl chicks. Sudan Journal of Science and Technology 20(2): 22-26. https://doi.org/10.4236/oalib.1106463
10. Makky, E.A.M., Aldood, M.E., Dafalla, R.A.H. (2017). Administration of ketamine hydrochloride as general anesthesia in domestic fowl. Sudan University of Science and Technology. http://repository.sustech.edu/handle/123456789/23914

11. Samour, J.H., Jones, D.M., Knight, J.A., Howlett, J.C. (1984). Comparative studies of the use of some injectable anaesthetic agents in birds. Vet Rec. 115(1): 6-11.

https://doi.org/10.1136/vr.115.1.6

12. Gessner, P.K. (1995). Isobolographic analysis of interactions: an update on applications and utility. Toxicology 105(2-3): 161-179. https://doi.org/10.1016/0300-483X(95)03210-7

13. Dixon, W.J. (1980). Efficient analysis of experimental observations. Annu Rev Pharmacol Toxicol. 20(1): 441-462.

https://doi.org/10.1146/annurev.pa.20.040180.002301

14. Naser, A.S., Amin, Y.M. (2019). Analgesic effect of silymarin in chicks. Iraqi J Vet Sci. 33(2): 273-276. https://doi.org/10.33899/ijvs.2019.162906

15. Naser, A.S., Albadrany, Y., Shaaban, K.A. (2020). Isobolographic analysis of analgesic interactions of silymarin with ketamine in mice. J Hell Vet Med Soc. 71(2): 2171-2178. https://doi.org/10.12681/jhvms.23653

16. Alatrushi, A.N., Naser, A.S. (2021). Evaluation of the anesthetic action of alfaxalone in chicks and compared with alfaxalone/ketamine or alfaxalone/ xylazine. Egypt J Vet Sci. 52(2): 221-228. https://doi.org/10.21608/ejvs.2021.60507.1215

17. Gupta, P.K. (2016). Fundamentals of toxicology: essential concepts and applications. (pp. 22-41). Academic Press. Amsterdam: Elsevier

18. Naser, A.S., Mohammad, F.K. (2014). Central depressant effects and toxicity of propofol in chicks. Toxicol Reports. 1, 562-568. https://doi.org/10.1016/j.toxrep.2014.08.003

19. Tallarida, R.J. (1992). Statistical analysis of drug combinations for synergism. Pain 49(1): 93-97. https://doi.org/10.1016/0304-3959(92)90193-F

20. Puig, M.M., Warner, W., Pol, O. (2000). Intestinal inflammation and morphine tolerance alter the interaction between morphine and clonidine on gastrointestinal transit in mice. $\mathrm{J}$ Am Soc Anesthesiol. 93(1): 219-230. https://doi.org/10.1097/00000542-200007000-00033

21. Naser, A.S., Mohammad, F.K. (2014). Isobolographic analysis of sedative and hypnotic interactions of propofol with ketamine and xylazine in chicks. Hum Vet Med. 6(2): 56-60. 
22. Punch, P.I.P. (2001). A retrospective study of the success of medical and surgical treatment of wild Australian raptors. Aust Vet J. 79(11): 747-752. https://doi.org/10.1111/j.1751-0813.2001.tb10890.x

23. Smith, S., Rodriguez-Barbon, A. (2008). Waterfowl: medicine and surgery. BSAVA Man Farm Pets Gloucester, UK Br Small Anim Vet Assoc. 250-273.

24. Curtis, R., Jemmett, J.E., Hendy, P.G. (1977). Saffan (CT 1341) as an anaesthetic agent for the budgerigar Melopsittacus undulatus. J Small Anim Pract. 18(7): 465-472.

https://doi.org/10.1111/j.1748-5827.1977.tb05914.x

25. Erickson, R.L., Blevins, C.E., De Souza Dyer, C., Marx, J.O. (2019). Alfaxalone-xylazine anesthesia in laboratory mice (Mus musculus). J Am Assoc Lab Anim Sci. 58(1): 30-39.

https://doi.org/10.30802/AALAS-JAALAS-18-000010

26. Siriarchavatana, P., Ayers, J.D., Kendall, L.V. (2016). Anesthetic activity of alfaxalone compared with ketamine in mice. J Am Assoc Lab Anim Sci. 55(4): 426-430.

27. Heng, K., Marx, J.O., Jampachairsi, K., Huss, M.K., Pacharinsak, C. (2020). Continuous rate infusion of alfaxalone during ketamine-xylazine anesthesia in rats. J Am Assoc Lab Anim Sci. 59(2): 170-175. https://doi.org/10.30802/AALAS-JAALAS-19-000122
28. Keates, H.L., van Eps, A.W., Pearson, M.R.B. (2012). Alfaxalone compared with ketamine for induction of anaesthesia in horses following xylazine and guaifenesin. Vet Anaesth Analg. 39(6): 591-598. https://doi.org/10.1111/j.1467-2995.2012.00756.x

29. Muñoz, K.A., Robertson, S.A., Wilson, D.V. (2017). Alfaxalone alone or combined with midazolam or ketamine in dogs: intubation dose and select physiologic effects. Vet Anaesth Analg. 44(4): 766-774.

https://doi.org/10.1016/j.vaa.2017.01.004

30. Khenissi, L., Nikolayenkova-Topie, O., Broussaud, S., Touzot-Jourde, G. (2017). Comparison of intramuscular alfaxalone and ketamine combined with dexmedetomidine and butorphanol for castration in cats. J Feline Med Surg. 19(8): 791-797. https://doi.org/10.1177/1098612X16657951

31. Tanaka, K., An, B.K., Banno, C., Xia, Z.S., Ohtani, S. (1997). Effects of dietary fat sources on lipid metabolism in growing chicks (Gallus domesticus). Comp Biochem Physiol Part B Biochem Mol Biol. 116(1): 119-125.

https://doi.org/10.1016/S0305-0491(96)00182-4

Please cite this article as: Alatrushi A.N., Naser A.S. The safety profile of the anesthetic effect of alfaxalone and its interaction with xylazine and ketamine in chick's model (Gallus gallus domesticus). Mac Vet Rev 2021; 44 (2): 203-209.

https://doi.org/10.2478/macvetrev-2021-0025 